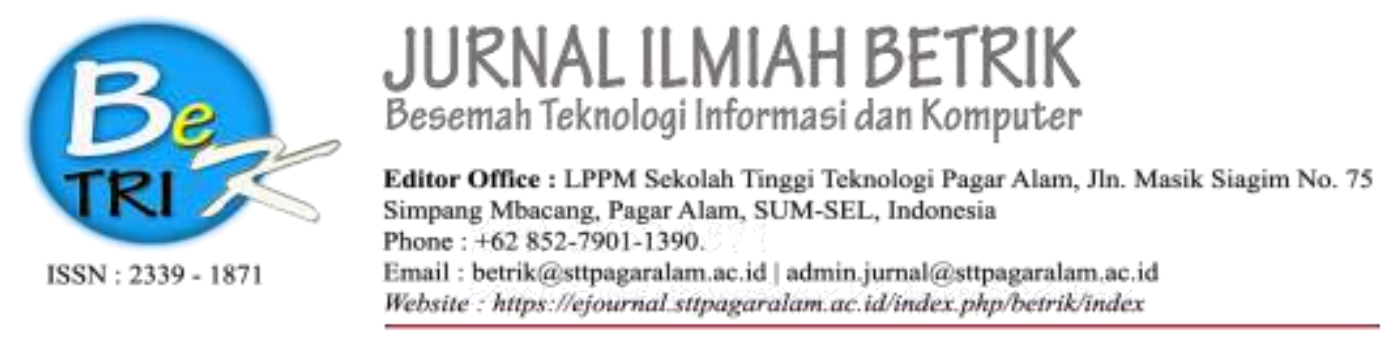

\title{
RANCANG BANGUN WEBSITE PADA SEKOLAH MENENGAH PERTAMA (SMP) NEGERI 2 GUMAY ULU
}

\author{
Alfis Arif \\ Program Studi Teknik Informatika Sekolah Tinggi Teknologi Pagar Alam \\ Jalan Masik Siagim No.75 Simpang Mbacang Kec.Dempo Tengah Kota Pagar Alam \\ Sur-el :alfisarif@yahoo.com
}

\begin{abstract}
Abstrak: Penelitian dengan judul "Rancang Bangun Website SMP Negeri 2 Gumay Ulu berbasis Web" telah di laksanakan dengan tujuan untuk merancang dan membangun website SMP Negeri 2 Gumay Ulu yang dapat menyampaikan informasi kepada masyarakat ataupun pengunjung secara online. Website ini dirancang dengan menggunakan pemodelan $U M L$. Sedangkan bahasa pemrograman yang di gunakan adalah PHP Database dan MySQL. Hasil dari Rancang Bangun ini adalah website yang mana website ini di titik beratkan pada pengolahan informasi mengenai sekolah-sekolah dan kegiatan yang ada di sekolah seperti ekskul, program - program keahlian ilmu kemasyarakatan dan Tersebut. Metode pengembangan sistem yang di pakai dalam web Engineering (rekayasa web) dengan tahapan sebagai berikut: Customer Communication, Planning, Modelling, Construction, Deployment. Dengan adanya Website SMP Negeri 2 Gumay Ulu diharapkan dapat membantu penyampaian informasi yang cepat, dan tidak banyak menggunakan media kertas,dan tentunya memudahkan pengolahan data dan penyampaian informasi melalui website itu sendiri.
\end{abstract}

Kata Kunci : Rancang Bangun, Website, PHP Database Dan MySQL.

Abstract: Research with the title of website design SMP 2 Gumay Ulu Website that can convey information to the public or visitors online. This website is designed by using UMLl modeling while the programming language used is PHP Database And MySQL result of website design where the Website is in the point emphasize on pengelolahan information about school schools and activities that exist in schools such as ekskul program science and community science program the system development method used in web engineering web engineering with stages as follows Customer Communication, Planning, Modelling, Cunstruction, Deployment. with the Website SMP 2 Gumay Ulu can help the delivery of information quickly and do not use paper media and certainly facilitate pengelolahan data and delivery of information through the website itself.

Keywords : Design Build, Website, PHP, Database dan MySQL

\section{PENDAHULUAN}

Teknologi Informasi merupakan salah satu pemicu terjadinya perubahan pola pikir manusia untuk dapat memperoleh informasi secara cepat dan akurat. Internet sebagai salah satu media Teknologi Informasi sangat besar manfaatnya bagi masyarakat yang membutuhkan informasi tanpa terhalang oleh jarak dan perbedaan yang sebelumnya menjadi penghambat dalam penyebaran informasi. Berkembangnya ilmu pengetahuan dan teknologi pada saat ini dan penerapan teknologi komputer dalam setiap aspek kehidupan sudah dianggap sebagai suatu kebutuhan, hal ini terjadi karena penerapan teknologi komputer dirasakan bisa membuat sebuah pekerjaan menjadi lebih cepat dan mudah. 
Sistem informasi web merupakan media yang digunakan untuk menampilkan informasi mengenai suatu informasi melalui media interaksi seperti media gambar, video, audio atau gabungan dari semua media tersebut dan kombinasi teratur dari orang-orang, perangkat keras (hardware), perangkat lunak (sofware), jaringan komunikasi dan sumber daya data yang menggumpulkan, mengubah dan menyebarkan informasi dalam sebuah organisasi. Sistem informasi juga merupakan suatu sistem yang terdiri dari brainware, data dan prosedur untuk menjalankan input, proses output, pernyimpanan dan pengontrolan yang mengubah sumber dan menjadi sistem informasi. (Putra, 2014). Informasi merupakan hasil pengolahan data dari suatu atau berbagai sumber, yang kemudian diolah, sehingga memberikan nilai, arti, dan manfaat. Proses pengolalaan ini memerlukan teknologi memang tidak harus selalu berkaitan dengan komputer, namun komputer sendiri merupakan salah satu bentuk teknologi (Pratama I. P., 2014).

Sebagai media informasi dan komunikasi, website menjadi pilihan yang paling tepat dalam mengimplementasikan sistem informasi disekolah. Website dapat diakses oleh siapa saja dan dimana saja tanpa dibatasi waktu dan tempat. Untuk mengakses sebuah wabsite, seseorang cukup menggunakan seperangkat komputer yang terhubung ke internet. (Eko, 2014). Berdasarkan hasil Penelitian (Membara, 2014) dengan judul Website Sekolah Menengah Pertama Negeri 2 Talang Empat sebagai media alternatif penyedia informasi, sehingga mempermudah dalam pencarian data mengenai Sekolah Menengah Pertama Negeri 2 Talang Empat. Dalam Sistem Informasi Akademik Sekolah Menengah Pertama
Negeri 2 Talang Empat berbasis Web terbagi menjadi beberapa Menu yaitu menu utama, menu home, menu informasi, menu materi, menu berita, menu galeri, menu buku tamu dan menu admin. Untuk informasi terdiri dari sub menu data kelas, sub menu informasi data guru, sub menu informasi data siswa, sub menu informasi data Nilai, sub menu informasi data Alumni dan sub menu informasi data pembelajaran.

Penelitian (Wigati, 2012) dengan judul Website SMP Negeri 262 ini telah berhasil dibuat dengan menggunakan $H T M L, \quad P H P$, dan $M y S Q L$. Pada website ini terdapat informasi tentang info sekolah, profil sekolah, fasilitas, prestasi -prestasi, dan informasi lain yang berhubungan dengan kesiswaan dan kurikulum. Dengan demikian maka perancangan dan pembuatan website SMP Negeri 262 ini diharapkan dapat memberikan kemudahan bagi masyarakat untuk memperoleh informasi yang dibutuhkan, serta memberi pengaruh besar bagi sekolah dalam mempromosikan sekolahnya. Website ini telah diunggah dan sudah dapat diakses di alamat:www.smpn262jakarta.sch.id. Berdasarkan hasil pengujian dari kuisioner yang telah disebarkan kepada 50 orang responden, didapat hasil $77 \%$ dari 50 orang responden menyukai dan setuju bahwa website ini mudah digunakan untuk mencari informasi yang berkaitan dengan SMP Negeri 262 Jakarta Timur. Dengan adanya sistem ini akan membantu pihak sekolah untuk mempromosikan atau mengenalkan SMP Negeri 2 Gumay Ulu kepada masyarakat luas bahwa SMP Negeri 2 Gumay Ulu ini sekarang sudah memiliki beberapa keunggulan dibandingkan dengan SMP lain. Berdasarkan 
uraian dan latar belakang diatas, maka peneliti mengangkat judul "Rancang Bangun Website Pada Sekolah Menengah Pertama Negeri 2 Gumay Ulu".

\section{METODOLOGI PENELITIAN}

\subsection{Metode Pengembangan Sistem}

Metode pengembangan sistem secara umum bisa diartikan sebagai urutan langka-langka yang tersektruktur untuk mengembangkan sebuah sistem informasi berbasis komputer dalam referensi, metode Metode lain metode pengembangan sistem diistilahkan dengan sistem development methodology atau rekayasa perangkat lunak (Software Enginnering) (Taufiq, 2013). Dalam pengembangan sistem yang digunakan dalam penulisan penelitian ini adalah metode $\mathrm{Web}$ Engineering dengan tahapan sebagai berikut :

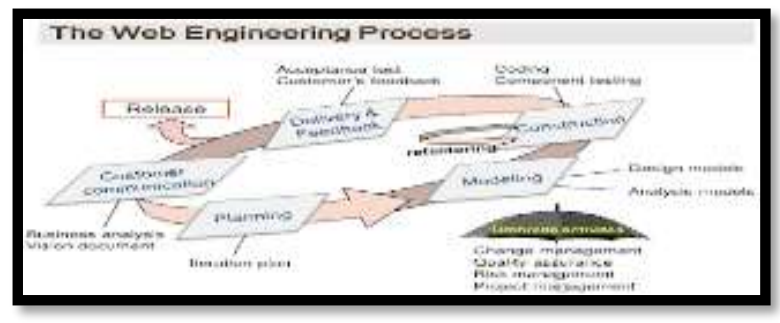

Gambar 1: Tahapan-Tahapan Proses Web

$$
\text { Engineering }
$$

Tahapan tersebut antara lain:

1. Customer Comunication (komsunikasi dengan pengguna)

Pada proses WebE, komunikasi dengan pengguna dikarakteristikkan dengan dua aktivitas utama: analisa bisnis dan formulasi. Analisa bisnis didfinisikan berkaitan dengan konteks bisnis/organisasi yang berkaitan dengan WebApp. Selanjutnya, stakeholders diidentifikasikan, perubahan iklim bisnis yang potensial atau permintaan pasar diprediksi, dan integrasi antara WebApp dan aplikasi bisnis lainnya, database, dan fungsi diidentifikasikan.
Formulasi adalah sebuah aktifitas pengumpulan kebutuhan yang melibatkan seluruh stakeholders. Tujuannya adalah untuk mendeskripsikan masalah yang perlu diselesaikan engan menggunakan informasi yang ada.

2. Planning (perencanaan)

Perencanaan dilakukan dari definisi tugas dan jadwal pekerjaan untuk jangka waktu tertentu yang diproyeksikan untuk peluncuran WebApp.

3. Modelling (pemodelan)

Teknik software konvensional menganalisa dan mendesain tugas yang di adaptasikan untuk mengembangkan WebApp, menggabungkan, dan kemudian menyatukannya dalam kegiatan pemodelan WebE. Tujuannya adalah untuk menggembangkan analisa "cepat" dan mendesain model yang menetapkan kebutuhan dan pada waktu yang sama merepresentasikan sebuah WebApp yang akan memuaskan mereka.

4. Construction (konstruksi)

Perangkat WebE dan teknologinya diaplikasikan untuk membuat WebApp yang telah jadikan model. Pada saat WebApp telah dibuat, serangkaian tes yang cepat dilakukan untuk mengukur kesalahan dalam desain tersebut.

5. Deployment (penyebaran)

WebApp dikonfigurasikan untuk lingkup operasionalnya, diluncurkan pada para penguna akhir, dan kemudian adanya tahap evaluasi. Umpan balik disaikan pada tim WebE, dan perbaikan dilakukan sesuai kebutuhan. 


\subsection{Use Case Diagram}

Rancangan Use case Diagram Website SMP Negeri 2 Gumay Ulu menggambarkan interaksi antara aktor dengan sistem yang dibuat. Dengan Use Case ini dapat diketahui proses yang terjadi pada aktivitas yang berjalan. Seperti rancangan use case diagram Website SMP Negeri 2 Gumay Ulu, dibawah ini :

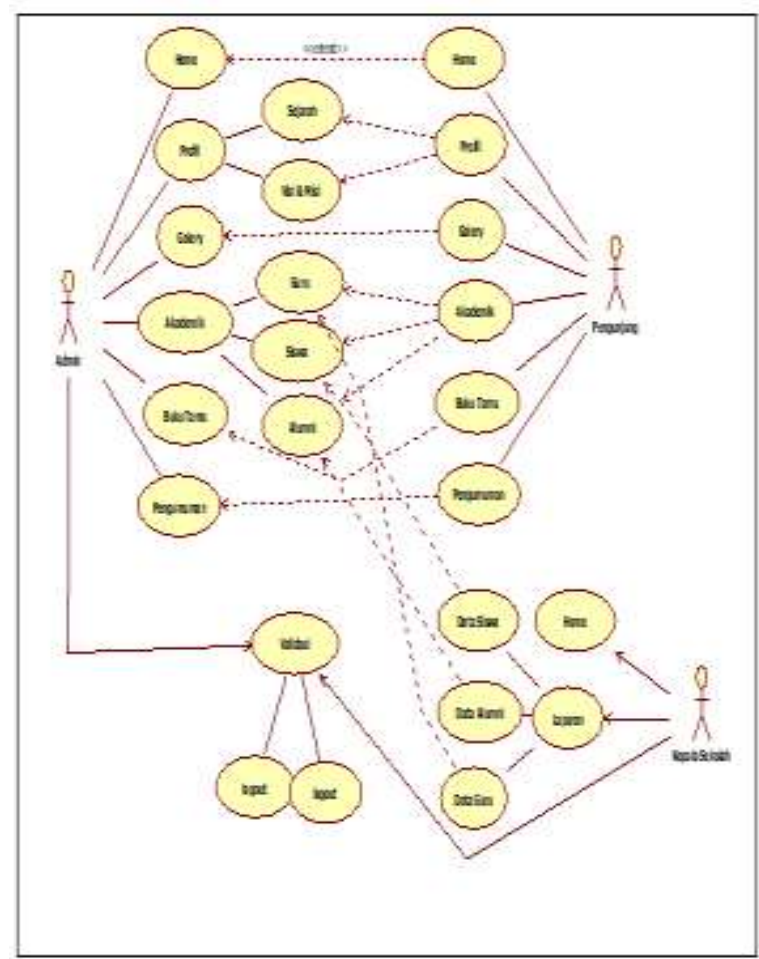

Gambar 2: Use Case Diagram yang diusulkan

\subsection{Class Diagram}

Diagram kelas atau class diagram pada SMP Negeri 2 Gumay Ulu.

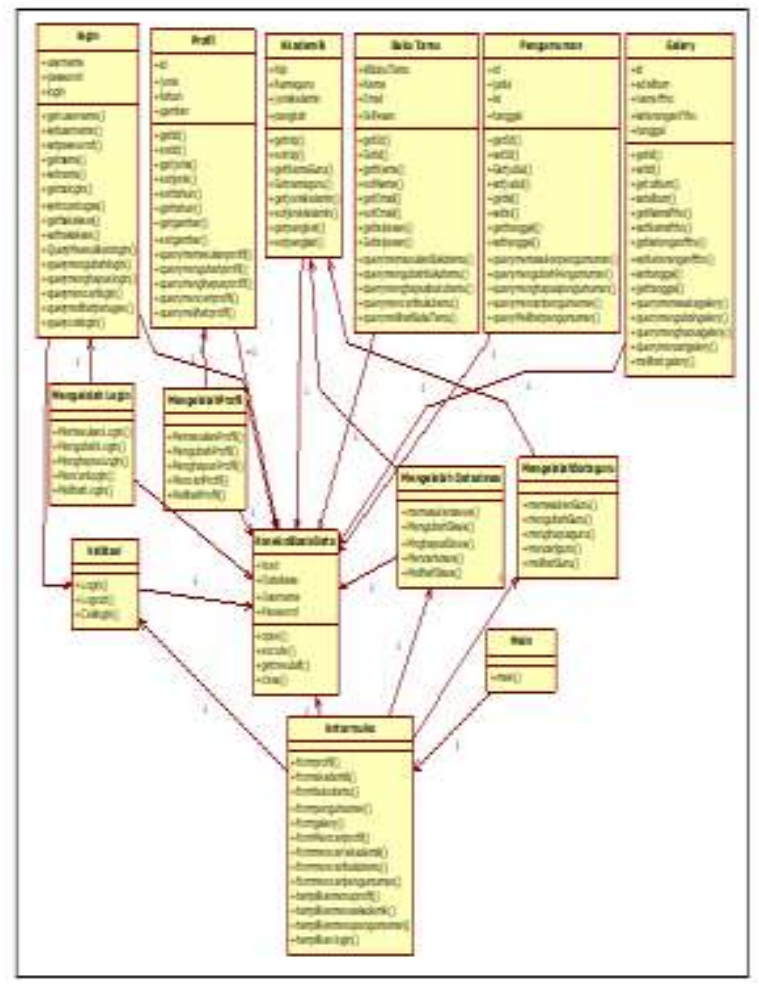

Gambar 3: Class Diagram Sistem

\subsection{Desain Tabel}

1. Tabel Admin

\begin{tabular}{cllcl}
\hline No & Name & Type & $\begin{array}{c}\text { Siz } \\
\boldsymbol{e}\end{array}$ & $\begin{array}{c}\text { Keteranga } \\
\mathbf{n}\end{array}$ \\
\hline 1 & id* & Int & 4 & Identitas \\
\hline 2 & $\begin{array}{l}\text { Usernam } \\
\text { e Varchar }\end{array}$ & 25 & ? Username \\
\hline 3 & $\begin{array}{l}\text { Passwor } \\
d\end{array}$ & Varchar & 25 & kata sandi \\
\hline 4 & Level & Varchar & & Level \\
\hline
\end{tabular}

Ket : * Primary Key

2. Tabel Guru

\begin{tabular}{ccccl}
\hline No & Name & Type & $\begin{array}{c}\text { Siz } \\
\boldsymbol{e}\end{array}$ & Keterangan \\
\hline 1 & NIP* & $\begin{array}{c}\text { Varch } \\
\text { ar }\end{array}$ & 50 & $\begin{array}{l}\text { No induk } \\
\text { pegawai }\end{array}$ \\
\hline 2 & $\begin{array}{l}\text { Nama } \\
\text { Guru }\end{array}$ & $\begin{array}{c}\text { Varch } \\
\text { ar }\end{array}$ & 35 & Nama Guru \\
\hline 3 & $\begin{array}{l}\text { Jenis_ } \\
\text { kelami } \\
\text { n }\end{array}$ & $\begin{array}{c}\text { Varch } \\
\text { ar }\end{array}$ & 9 & Jenis Kelamin \\
\hline 4 & $\begin{array}{l}\text { Tangg } \\
\text { al_lahi } \\
\text { r }\end{array}$ & Date & - & Tempat Lahir \\
& & &
\end{tabular}




\begin{tabular}{clccl}
\hline 5 & $\begin{array}{l}\text { No_Te } \\
\text { lepon }\end{array}$ & $\begin{array}{c}\text { Varch } \\
\text { ar }\end{array}$ & 30 & Telepon \\
\hline 6 & Email & $\begin{array}{c}\text { Varch } \\
\text { ar }\end{array}$ & 45 & Email \\
\hline 7 & $\begin{array}{l}\text { Pangk } \\
\text { at }\end{array}$ & $\begin{array}{c}\text { Varch } \\
\text { ar }\end{array}$ & 35 & Golongan \\
\hline 8 & $\begin{array}{l}\text { Pendid } \\
\text { ikan_t } \\
\text { erakhir }\end{array}$ & $\begin{array}{c}\text { Varch } \\
\text { ar }\end{array}$ & 34 & Masa kerja \\
\hline 9 & $\begin{array}{l}\text { Alama } \\
\text { t }\end{array}$ & Text & - & Alamat \\
\hline 10 & Foto & $\begin{array}{c}\text { Varch } \\
\text { ar }\end{array}$ & 100 & Foto \\
\hline Ket & Primary Key & &
\end{tabular}

Ket : * Primary Key

\section{Tabel Siswa}

\begin{tabular}{|c|c|c|c|c|}
\hline No & Name & Type & $\begin{array}{c}\mathrm{Siz} \\
e\end{array}$ & Keterangan \\
\hline 1 & Nis* & $\begin{array}{c}\text { Varch } \\
\text { ar }\end{array}$ & 30 & $\begin{array}{l}\text { Nomor } \\
\text { induk siswa }\end{array}$ \\
\hline 2 & $\begin{array}{l}\text { Nm_sis } \\
\text { wa }\end{array}$ & $\begin{array}{c}\text { Varch } \\
\text { ar }\end{array}$ & 25 & Nama siswa \\
\hline 3 & Kls & $\begin{array}{c}\text { Varch } \\
\text { ar }\end{array}$ & 60 & Kelas \\
\hline 4 & Alamat & $\begin{array}{c}\text { Varch } \\
\text { ar }\end{array}$ & 10 & Alamat \\
\hline 5 & $\mathrm{Jk}$ & $\begin{array}{c}\text { Varch } \\
\text { ar }\end{array}$ & 12 & $\begin{array}{l}\text { Jenis } \\
\text { kelamin }\end{array}$ \\
\hline 6 & Agama & $\begin{array}{c}\text { Varch } \\
\text { ar }\end{array}$ & 25 & Agama \\
\hline 7 & $\begin{array}{l}\text { Tmp_la } \\
\text { hir }\end{array}$ & $\begin{array}{c}\text { Varch } \\
\text { ar }\end{array}$ & 25 & Tempat lahir \\
\hline 8 & $\begin{array}{l}\text { Tgl_lahi } \\
\mathrm{r}\end{array}$ & Date & 35 & $\begin{array}{l}\text { Tanggal } \\
\text { lahir }\end{array}$ \\
\hline 9 & Email & $\begin{array}{c}\text { Varch } \\
\text { ar }\end{array}$ & 25 & Email \\
\hline 10 & Gambar & $\begin{array}{c}\text { Varch } \\
\text { ar }\end{array}$ & 100 & Foto \\
\hline 11 & No_hp & $\begin{array}{c}\text { Varch } \\
\text { ar }\end{array}$ & 25 & No telpon \\
\hline 12 & $\begin{array}{l}\text { Nama_ } \\
\text { OrangT } \\
\text { ua }\end{array}$ & $\begin{array}{l}\text { Varch } \\
\text { ar }\end{array}$ & 33 & $\begin{array}{l}\text { Nama orang } \\
\text { tua }\end{array}$ \\
\hline
\end{tabular}

Ket : * Primary Key

\section{Tabel Profil}

\begin{tabular}{clccl}
\hline No & Name & Type & Size & Keterangan \\
\hline 1 & $\mathrm{Id}^{*}$ & Int & 4 & $\mathrm{Id}$ \\
\hline 2 & Judul & Varchar & 25 & Judul \\
\hline 3 & Isi & Text & - & Isi profil \\
\hline
\end{tabular}

Ket : * Primary Key

\section{Tabel Mata Pelajaran}

\begin{tabular}{ccccl}
\hline No & Name & Type & $\begin{array}{c}\text { Siz } \\
\boldsymbol{e}\end{array}$ & $\begin{array}{c}\text { Keteranga } \\
\text { n }\end{array}$ \\
\hline 1 & Id_mapel* $^{*}$ & Int & 5 & $\begin{array}{l}\text { Primary } \\
\text { key }\end{array}$ \\
\hline 2 & $\begin{array}{l}\text { Nama_Ma } \\
\text { pel }\end{array}$ & Int & 50 & $\begin{array}{l}\text { Nama } \\
\text { Pelajaran }\end{array}$ \\
\hline 3 & Kelas & $\begin{array}{c}\text { Varch } \\
\text { ar }\end{array}$ & 5 & Kelas \\
\hline
\end{tabular}

Ket : * Primary Key

\subsection{Desain Halaman Utama}

Masukkan Input merupakan awal dimulainya proses informasi, masukan Aplikasi pengolahan data adalah data yang merupakan bahan mentah dari informasi perancangan masukan, merupakan rancangan dari form yang digunakan untuk menangkap data, kode-kode input yang digunakan dari pada gambar berikut ini.

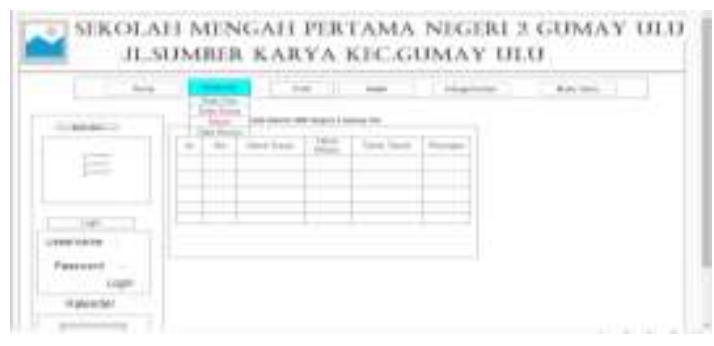

Gambar 4: Desain Halaman Utama

\subsection{Desain Form Data Guru}

Desain menu data guru merupakan tampilan dari halamam website yang berisi tentang data guru dimana user tersebut dapat melihat nama-nama guru yang tampil di halaman user tersebut.

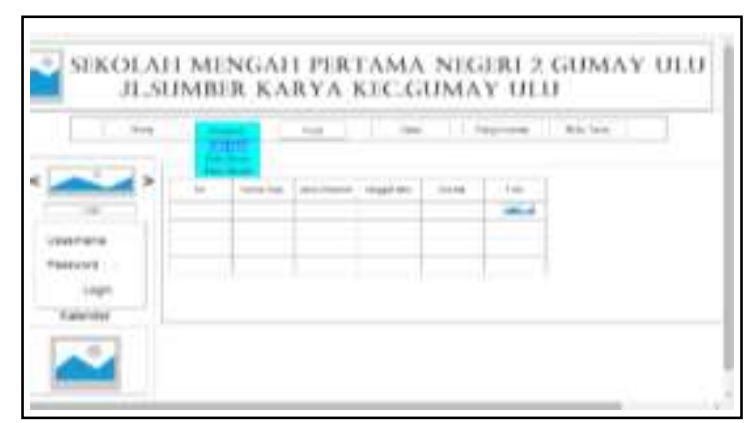

Gambar 5: Desain Data Guru 


\subsection{Desain Form Data Siswa}

Halaman ini berisi data siswa yang ada pada SMP Negeri 2 Gumay Ulu Berikut gambar rancangan data siswa SMP Negeri 2 Gumay ulu.

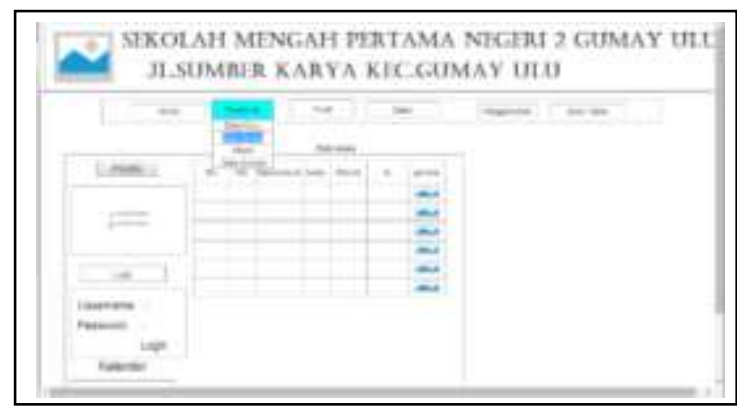

Gambar 6: Desain Form Data Siswa

\subsection{Desain Halaman Profil}

Tampilan menu profil. Berikut gambar rancangan halaman form profil.

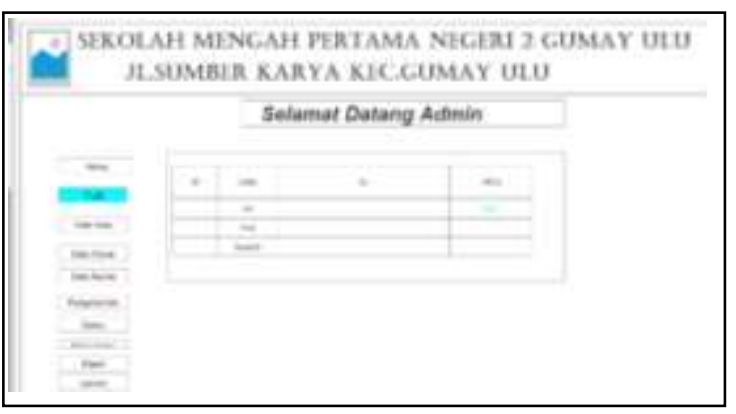

Gambar 7: Desain Halaman Profil

\subsection{Desain Halaman Mata Pelajaran}

Pada halam ini berisi mata pelajaran pada SMP Negeri 2 Gumay Ulu Berikut Gambar rancangan halaman utama mata pelajaran.

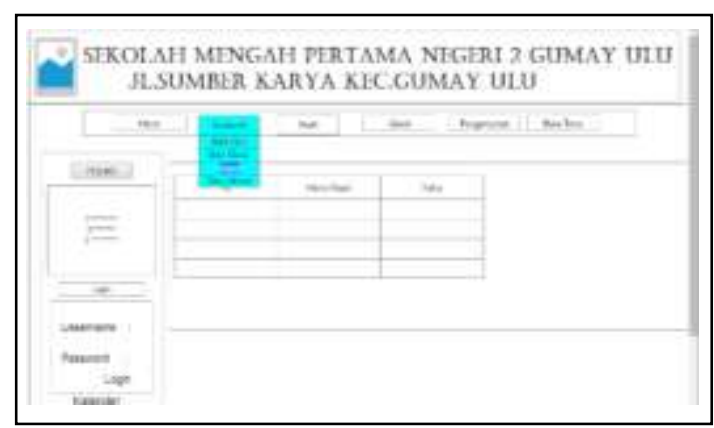

Gambar 8: Desain Mata Pelajaran

\section{HASIL DAN PEMBAHASAN}

\subsection{Hasil}

Hasil dari penelitian ini yaitu menghasilkan Website Sekolah Menengah Pertama Negeri 2 Gumay Ulu, yang berguna untuk membantu atau memperlancar penyebaran informasi tentang Sekolah tersebut. Oleh karena itu yang dilakukan dalam menyelesaikan desain sistem yang telah disetujui, untuk menguji, menginstal dan memulai sistem baru atau sistem yang diperbaiki untuk menggantikan sistem yang lama.

\subsection{Pembahasan}

Website Sekolah Menegah Pertama Negeri 2 Gumay Ulu memiliki beberapa halaman, yang mana tiap halamannya masing-masing memiliki link, yang tiap isi halaman web menunjukkan setiap informasi yang berbeda-beda. Adapun halaman - halaman yang ada di website Sekolah menengah Pertama Negeri 2 Gumay Ulu akan dijelaskan satu persatu seperti dibawah ini. Langkah-langkah mengoperasikan website ini yang pertama, aktifkan salah satu web browser seperti Mozilla firefox, internet explorer, opera, atau chrome. Kemudian masukkan URL localhost/SMP2 lalu tekan tombol enter pada keyboard, maka akan tampil website Sekolah Menengah Pertama Negeri 2 Gumay Ulu.

\subsubsection{Halaman Utama}

Halaman utama merupakan tampilan pertama saat kita membuka web Sekolah Menengah Pertama Negeri 2 Gumay Ulu. Tampilan halaman utama dapat kita lihat seperti gambar dibawah ini : 


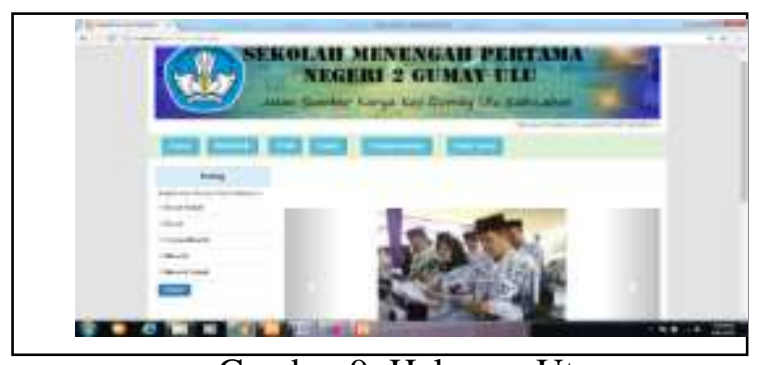

Gambar 9: Halaman Utama

\subsubsection{Halaman Login Admin}

Pada tampilan ini menu untuk login admin dan kepala sekolah, dimenu ini admin harus menginputkan username password kemudian login untuk mengakses selanjutnya. Berikut gambar tampilan login admin:

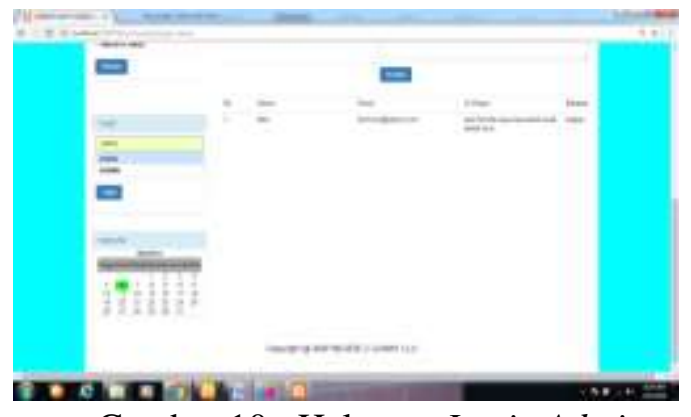

Gambar 10: Halaman Login Admin

\subsubsection{Halaman Menu Admin}

Halaman menu Admin ini berfungsi untuk melakukan pengolaan terhadap sistem sehingga dapat melakukan pengolaan terhadap sistem yang akan di kelola oleh Admin.

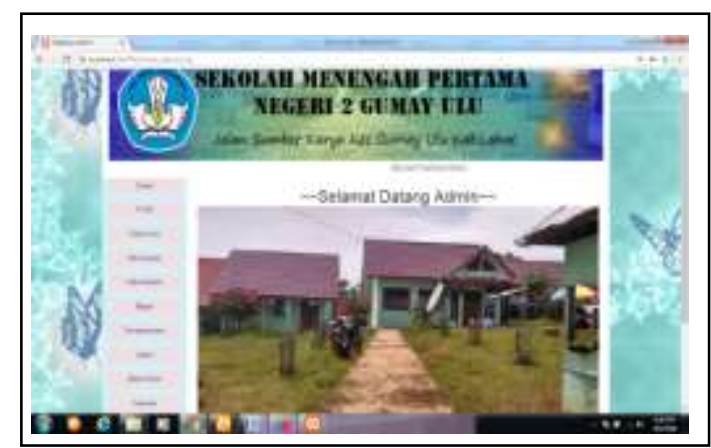

Gambar 11: Halaman Menu Admin

\subsubsection{Input data profil}

Pada halaman ini Admin dapat mengolah data profil yang terdiri dari Visi-Misi dan Sejarah. Berikut tampilanya :

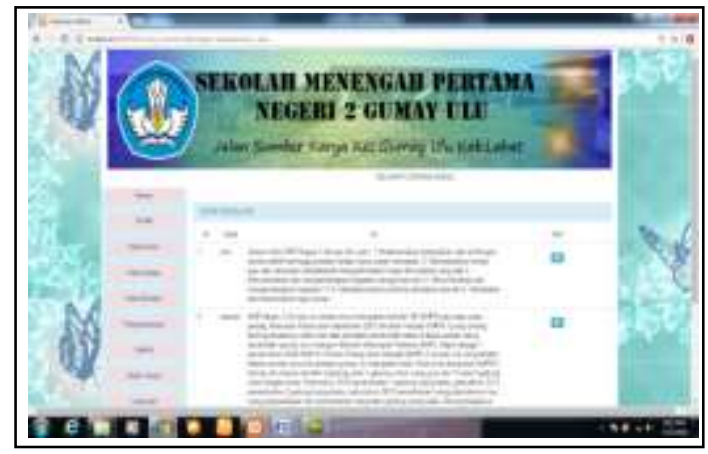

Gambar 12: Input Data Profil

\subsubsection{Output Data Profil}

Output data profil menampilkan hasil dari pemberitahuan tentang visi dan misi serta sejarah yang telah di inputkan. Berikut tampilannya:

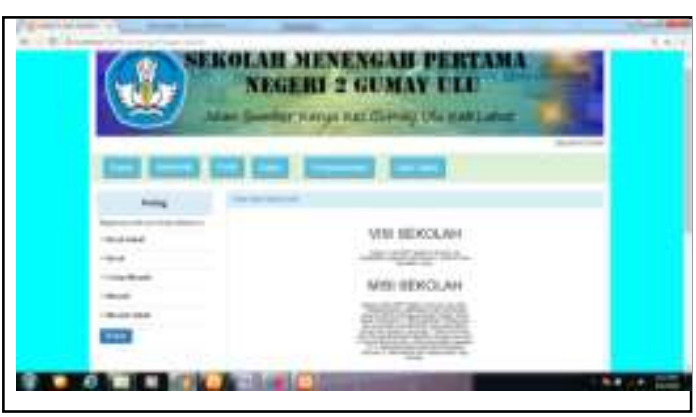

Gambar 13: Output Data Profil

\subsubsection{Input Data Guru}

Input data guru digunakan untuk menambahkan nama-nama guru yang ada di SMP Negeri 2 Gumay Ulu.

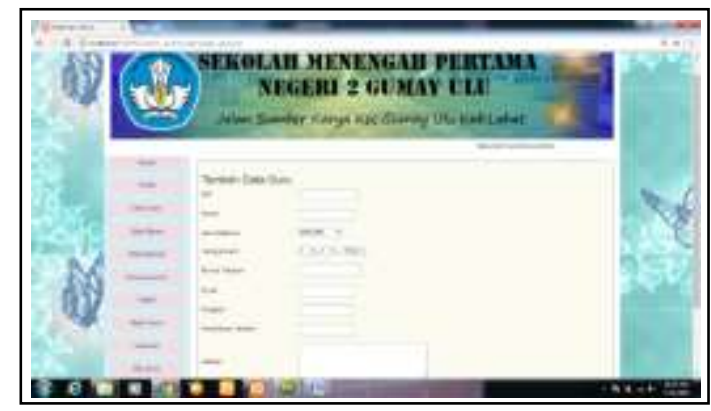

Gambar 14: Input Data Guru 


\subsubsection{Output Data Guru}

Output data guru berupa tampilan nama-nama guru yang ada pada SMP Negeri 2 Gumay Ulu. Output data guru dapat dilihat pada gambar dibawah ini:

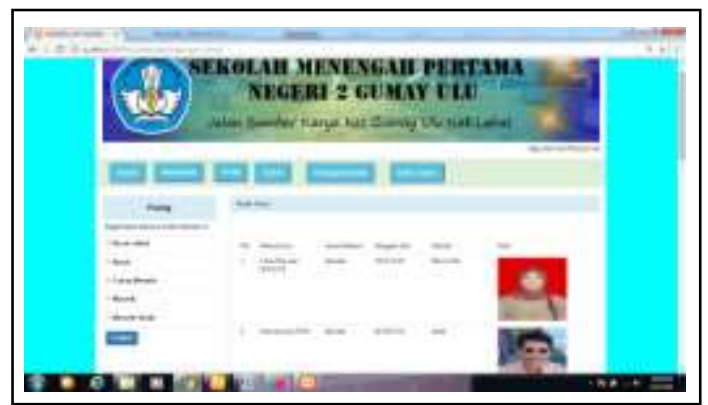

Gambar 15: Output Data Guru

\subsubsection{Input Data Siswa}

Input data siswa digunakan untuk menambah data siswa di SMP Negeri 2 Gumay Ulu. Input data siswa dapat dilihat pada gambar dibawah ini:

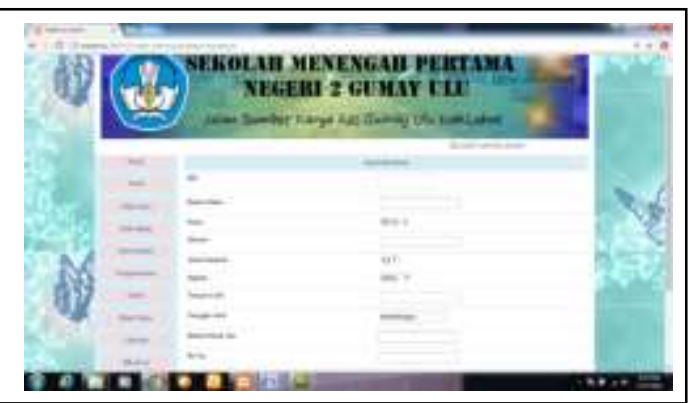

Gambar 16: Input Data Siswa

\subsubsection{Output Data Siswa}

Halaman output data siswa merupakan tampilan website, jika kepala sekolah meng-klik untuk melihat data siswa maka tampilan halaman data siswa yang ada pada SMP Negeri 2 Gumay Ulu. Berikut gambar rancangan tampilan data siswa.

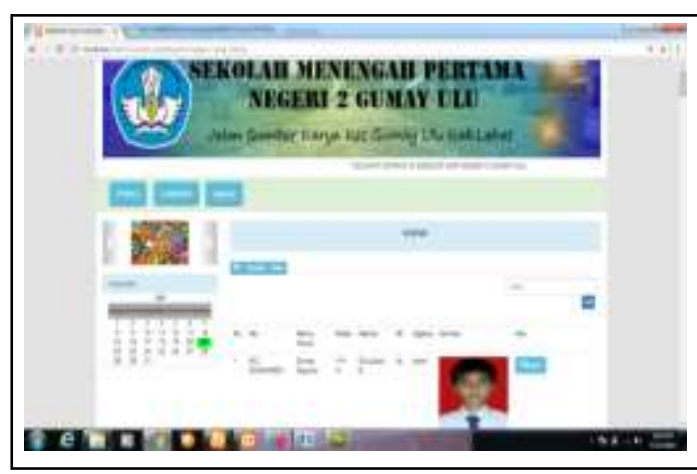

Gambar 17: Output Data Siswa

\subsubsection{Input Mata Pelajaran}

Pada halaman input data pelajaran dimana admin tersebut dapat menginfutkan mata pelajaran berdasarkan kelas masing-masing berikut tampilan tambah data pelajaran.

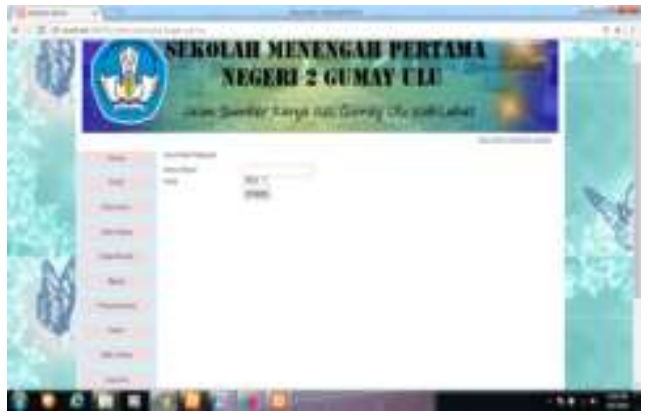

Gambar 18: Input Mata Pelajaran

\subsubsection{Output Mata Pelajaran}

Pada halaman mata pelajaran terdapat menu mata pelajaran dimana kelas masingmasing dapat melihat mata pelajaran yang telah diinputkan berdasarkan kelas masing-masing. Berikut gambar rancangan tampilan menu mata pelajaran pada SMP Negeri 2 Gumay Ulu.

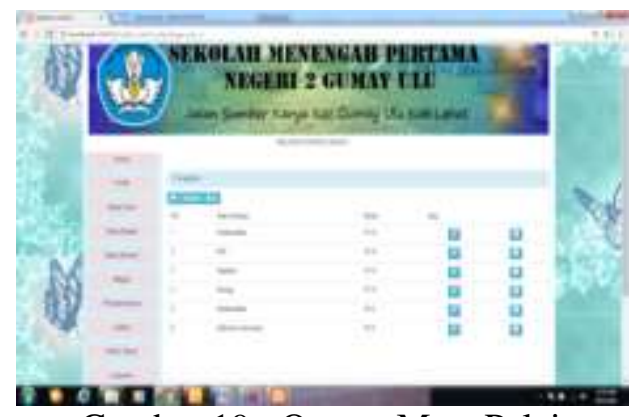

Gambar 19: Output Mata Pelajaran 


\section{SIMPULAN}

Dalam penelitian ini telah diuraikan bagaimana merancang dalam membangun website pada Sekolah Menengah Pertama Negeri 2 Gumay Ulu. Maka dari itu peneliti menyimpulkan :

1. Telah diselesaikannya pembuatan Website Sekolah menengah Pertama Negeri 2 Gumay Ulu ini dan dapat di akses oleh user yang ingin mengetahui informasi tentang Sekolah Menengah Pertama Negeri 2 Gumay Ulu Tersebut.

2. Desain halaman website yang menarik dan mudah dipahami sangat diperlukan dalam sebuah website agar user nyaman menggunakan website ini.

\section{DAFTAR PUSTAKA}

Alexander. (2013). Web Programming Power Pack. Yogyakarta : MediaKom.

Andi. (2013). Adobe Dreamweaver Cs6. Yogyakarta: Andi.

Andi. (2010). Metode Penelitian. Yogyakarta : Andi Offset.

Abdulloh, R (2016). Easy dan Simple Web Programming. Jakarta : Elex Media Komputindo

Eko, P. (2011). PHP \& jQUERY. Jogjakarta : MediaKom

Erni, W. (2012). Perancangan Website Sekolah Menengah Pertama Negeri 262 Cakung Jakarta Timur Dengan Menggunakan PHP dan MySQL Gunadarma University.

Fathansyah. (2015). Basis Data. Bandung : Informatika.

Junaidi, A. (2010). Wordpress dan joomla. Bandung.
Membara, E. P. (2014). Sistem Informasi Akademik SMP Negeri 2 Talang Empat Berbasis Web. Media Infotama .

Nusantara. B (2016). intrpduction to Axure. Retrieved from Bina Nusantara Website.

Oktaviani, N. (2015). Rancang Bangun Wesite SMP Azharyah Palembang. Sistem Informasi .

Pratama, I. P. (2014). Sistem Informasi dan Implementasinya.

Bandung:: Informatika.

Rosa.A.s. (2014). Rekayasa Perangkat Lunak Terstruktur Dan Berorientasi Objek. Bandung: Informatika.

Septima, A. (2012). Perancangan Sistem Informasi Berbasis Website Subsistem Guru di Sekolah Pesantren Persatuan Islam 99 Rancabango. Algoritma.

Sulaini, I. (2014). Permula, Internet Untuk Pemula Yogyakarta. Deepublish.

Taufiq, R. (2013). Sistem Informasi Manajemen Rohmat Taufiq. yogyakarta.

Wigati, E. (2012). Perancangan Website Sekolah Menengah Pertama Negeri 262 Cakung jakarta Timur Dengan Mengunakan PHP dan mySQL. Gurnadarma University, Information Technology. 